\title{
CLIMATIC RECORDS FROM THE DUNDE ICE CAP, CHINA
}

\author{
by \\ Lonnie G. Thompson*, Wu Xiaoling**, Ellen Mosley-Thompson* and Xie Zichu** \\ * (Byrd Polar Research Center, Ohio State University, \\ 125 South Oval Mall, Columbus, OH 43210, U.S.A.) \\ ** (Lanzhou Institute of Glaciology and Geocryology, Academia Sinica, \\ Lanzhou, Gansu, People's Republic of China)
}

\section{ABSTRACT}

Results from the first glaciological investigation of the Dunde ice cap demonstrate that a long, highly temporally resolvable climatic ice-core record is preserved in this ice cap. Measurements of stratigraphy, microparticle concentrations, liquid conductivity, and oxygen-isotope ratios from three snow pits in 1984 suggest that the annual accumulation is approximately $200 \mathrm{~mm}$ (water equivalent). Measurement of microparticle concentrations and conductivities of pit samples collected in 1986 confirm the existence of annual dust layers and an annual accumulation rate of $\sim 200 \mathrm{~mm} /$ year over the past 5 years. Bore-hole temperatures of $-5.4^{\circ} \mathrm{C}$ at $30 \mathrm{~m}$ indicate that the ice cap is polar. Mono-pulse radar depth determinations yield an average thickness of $140 \mathrm{~m}$, which (coupled with the smooth bedrock topography and the current accumulation rate) suggest that the Dunde ice cap should contain at least a 3000 year climatic record. A drilling program to recover that record from this subtropical location is planned for 1987.

\section{INTRODUCTION}

The inter-annual fluctuations in the summer monsoon rains over south-eastern Asia have a profound socioeconomic impact. Weak monsoons are associated with drought, crop failure, and (in extreme cases) famine. Strong monsoons are associated with devastating floods and the accompanying loss of life, property, and crops. The importance of the Tibetan plateau as a heat source for the atmosphere is well documented (Flohn 1957, 1965 and 1968, Koteswaram 1958, Murakami 1958 and 1981, Virgi unpublished, Yeh 1981, Luo and Yanai 1983, Reiter 1983, $\mathrm{Lau}$ and $\mathrm{Li}$ 1984). The climatic regime of eastern Asia is directly affected by the thermal and dynamical forcing by this extensive, elevated land mass. The sensible heat flux over the semi-arid western region of the plateau and latent heat release above the Himalaya contribute to a strong tropospheric heat source which maintains the large-scale Asian monsoon circulation. Not only do the Tibetan highlands determine the large-scale circulation, they also strongly influence synoptic-scale monsoon events in China (Lau and $\mathrm{Li}$ 1984).

Glaciers are widely scattered throughout the mountains and plateaus of western China and cover a total area of about $57000 \mathrm{~km}^{2}$ (Shi and Wang 1981). These glaciers have been studied by the scientists of the Lanzhou Institute of Glaciology and Geocryology. Inventories such as the "Glacier Inventory of China. I. Qilian Mountains" (Wang 1981) demonstrate that only a select few of these glaciers are ice caps at elevations high enough for the cold temperatures to preserve the stratigraphic record. Japanese glaciological expeditions to Nepal conducted extensive surveys on temperate glaciers there in 1973, 1974, 1975, 1976, and 1978 , and the results have been published in a special-issue series, "Glaciers and Climates of Nepal Himalayas" (Higuchi 1976, 1977, 1978, and 1980). Studies by Mayewski and others (1984) on ice cores up to $16.6 \mathrm{~m}$ long from the high-altitude temperate Sentik Glacier reveal that down-hole samples may have experienced some degree of post-depositional alteration, perhaps due to diffusion and/or melting. The most extensive study to date was conducted by Higuchi and others (1984), and in 1982 included ice-core recovery to a depth of $60 \mathrm{~m}$ from the $5400 \mathrm{~m}$ accumulation zone of the Yala Glacier in Langtang, Nepal. Temperature measurements at $10 \mathrm{~m}$ indicated that the glacier is temperate. Due to melt-water infiltration during summer, no seasonal oscillation in the vertical $\delta^{18} \mathrm{O}$ profile was found Finally, Niewodniczanski and others (1981) discussed, on a global scale which includes two parts of the Hindu Kush and the Himalaya, the isotopic composition of surface snows as a function of altitude in high mountains.

The Dunde ice cap $\left(38^{\circ} 06^{\prime} \mathrm{N}, 96^{\circ} 24.5^{\prime} \mathrm{E}\right)$ in the Qilian Shan mountains (Fig.1) provides an opportunity to recover the first lengthy ice-core record of climatic variability over the Tibetan plateau. The ice cap stretches $11 \mathrm{~km}$ from north-north-east to south-south-west, the width varies from 2.5 to $7.5 \mathrm{~km}$ and the total area of the ice cap is $57 \mathrm{~km}^{2}$. The central objective of the preliminary study (1984) was to evaluate the length and quality of the climatic record preserved in the Dunde ice cap. The first detailed investigation of the ice cap was conducted during the summer of 1986, with drilling to bedrock planned for the summer of 1987.

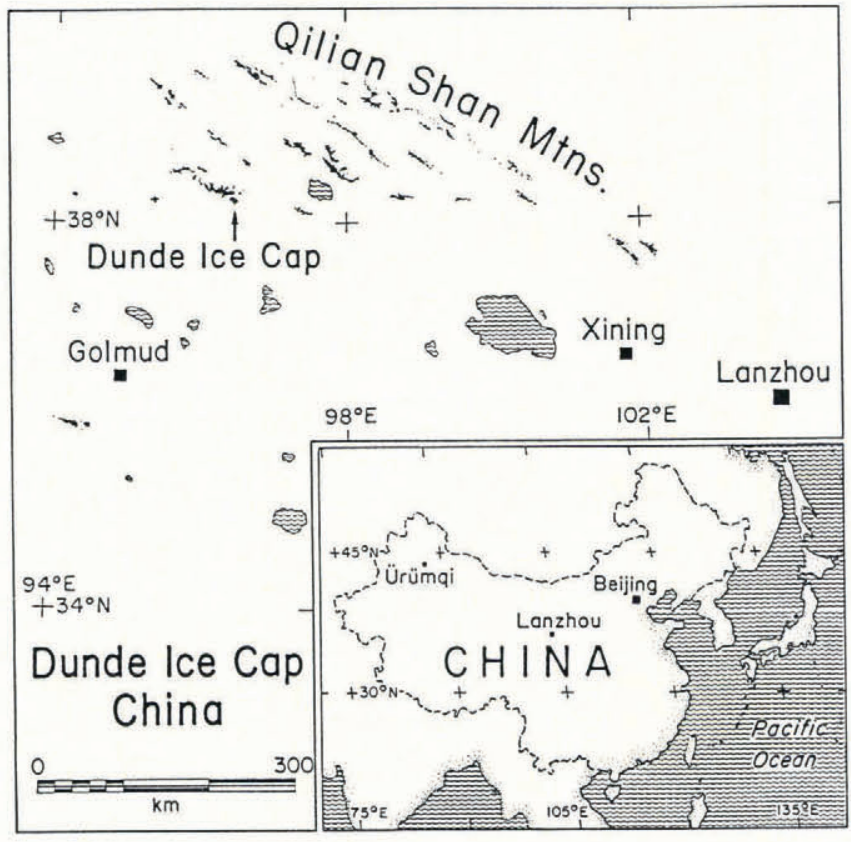

Fig.1. The Dunde ice cap is located in the Qilian Shan mountains of north-central China. 

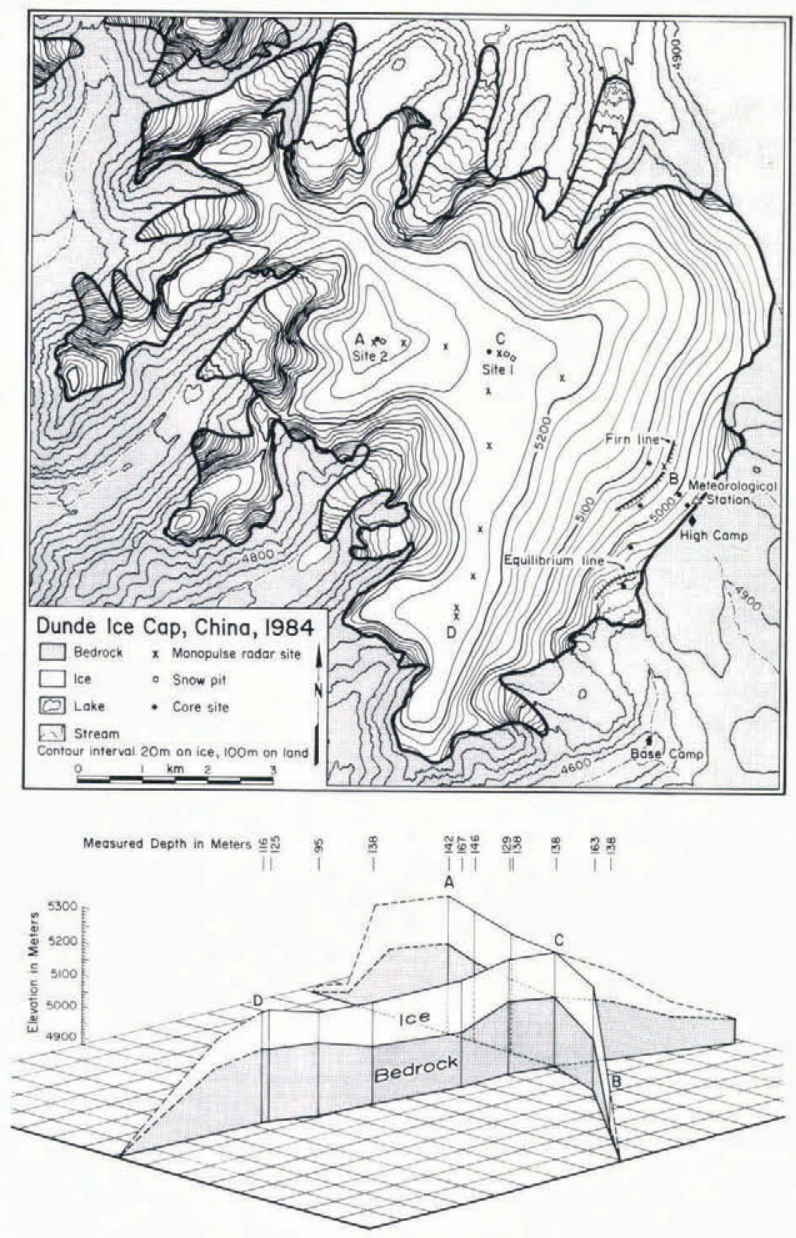

Fig.2. (a) This map of the Dunde ice cap shows sampling sites 1 and $2 ; \times$ indicates points where thickness determinations were made. (b) The ice-cap thicknesses along the NNE-SSW and WNW-ESE traverses were calculated from mono-pulse radar data collected at sites shown in Fig.2a.

\section{RESULTS}

A mono-pulse radar was used to determine the ice thickness at 12 sites along two traverses, one trending approximately north-south and the second trending east-west (Fig.2a). Ice thickness ranges from 94 to $167 \mathrm{~m}$, with an average thickness of $140 \mathrm{~m}$, and the bedrock topography is very smooth under much of the ice cap (Fig.2b). A series of five shallow cores was drilled at lower elevations on the ice cap in order to locate the equilibrium and firn lines. The equilibrium line and firn line occur at elevations of $4900 \mathrm{~m}$ and $5040 \mathrm{~m}$ respectively (Fig.2a). The firn line is inferred from the firn-to-ice transition and the equilibrium line is inferred from the initial occurrence of superimposed ice in the cores.

In order to evaluate the quality of the stratigraphic record preserved in the ice cap, samples were collected at two sites $2 \mathrm{~km}$ apart. At site $1(5250 \mathrm{~m}$ a.s.l.), located $4 \mathrm{~km}$ west of high camp on a flat part of the glacier, two $2 \mathrm{~m}$ snow pits, $20 \mathrm{~m}$ apart, were excavated to evaluate the horizontal continuity of the stratigraphy. Elevations given for pit sites in Figures 3,4 and 5 are those determined using a model AIR-HB-1A hand-held altimeter. The accuracy of the altimeter was verified with respect to a known benchmark in Golmud, $235 \mathrm{~km}$ south-west of the ice cap, before and after the 1986 field season. The visible stratigraphic record is revealed in thin but distinct dust layers in both pits. The walls of each pit were sampled for microparticle concentrations, liquid conductivity, and oxygen-isotope abundances. These results are illustrated in Figure 3, along with the densities and temperatures. Although the $1984,2 \mathrm{~m}$ ice temperatures averaged $-7.3^{\circ} \mathrm{C}$, there was evidence of seasonal snow melt resulting directly from the large seasonal temperature range and intense summer radiation. The vertical separation between the visible dust layers, along with measured densities, suggest that annual net accumulation has averaged approximately $200 \mathrm{~mm}$ of water equivalent from 1980 to 1984 .

At site $2(5400 \mathrm{~m}$ a.s.1.), located at the ice-cap summit and $2 \mathrm{~km}$ west of site 1 (Fig.2a), one $2 \mathrm{~m}$ pit was excavated and the walls were sampled in the same way as those at site 1. The stratigraphy was essentially identical with that found in both pits at site 1. The microparticle concentrations, liquid conductivity, and oxygen-isotope results from the pit are illustrated in Figure 4, along with

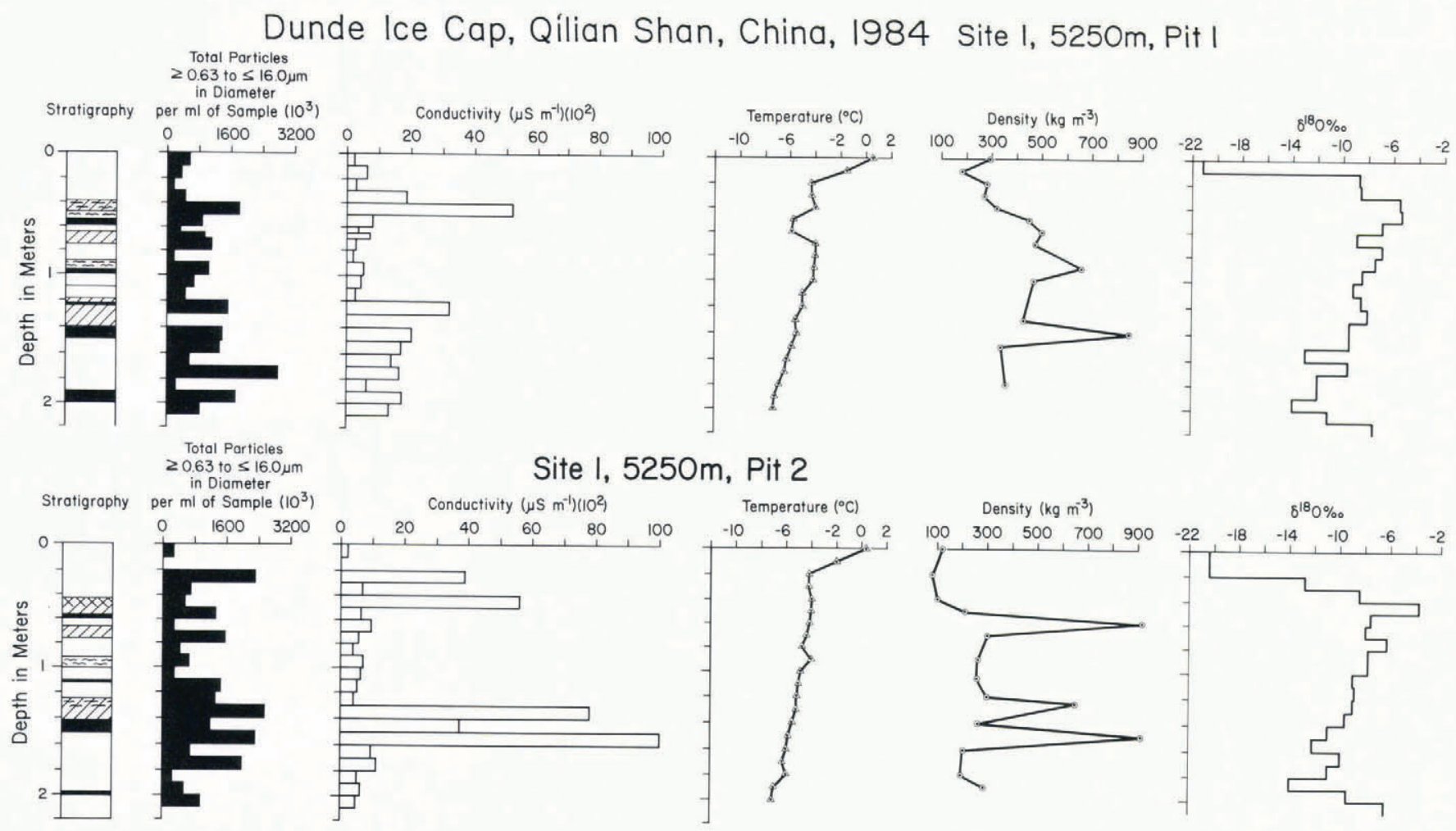

irty firn layer with very dirty upper layer

Ice

Dirty firn layer
Firn layer with ice lenses

Firn layer with ice lenses
Dirty firn layer with ice lenses

Fig.3. The stratigraphy, concentration of microparticles (diameters $\geqslant 0.63$ and $\leqslant 16.0 \mu \mathrm{m}$ per $\mathrm{ml}$ sample), liquid conductivity, tempe rature, density, and oxygen-isotope measurements from pit 1 (Fig.2a) and pit 2 (Fig.2b) at site 1. The two pits are $20 \mathrm{~m}$ apart. 


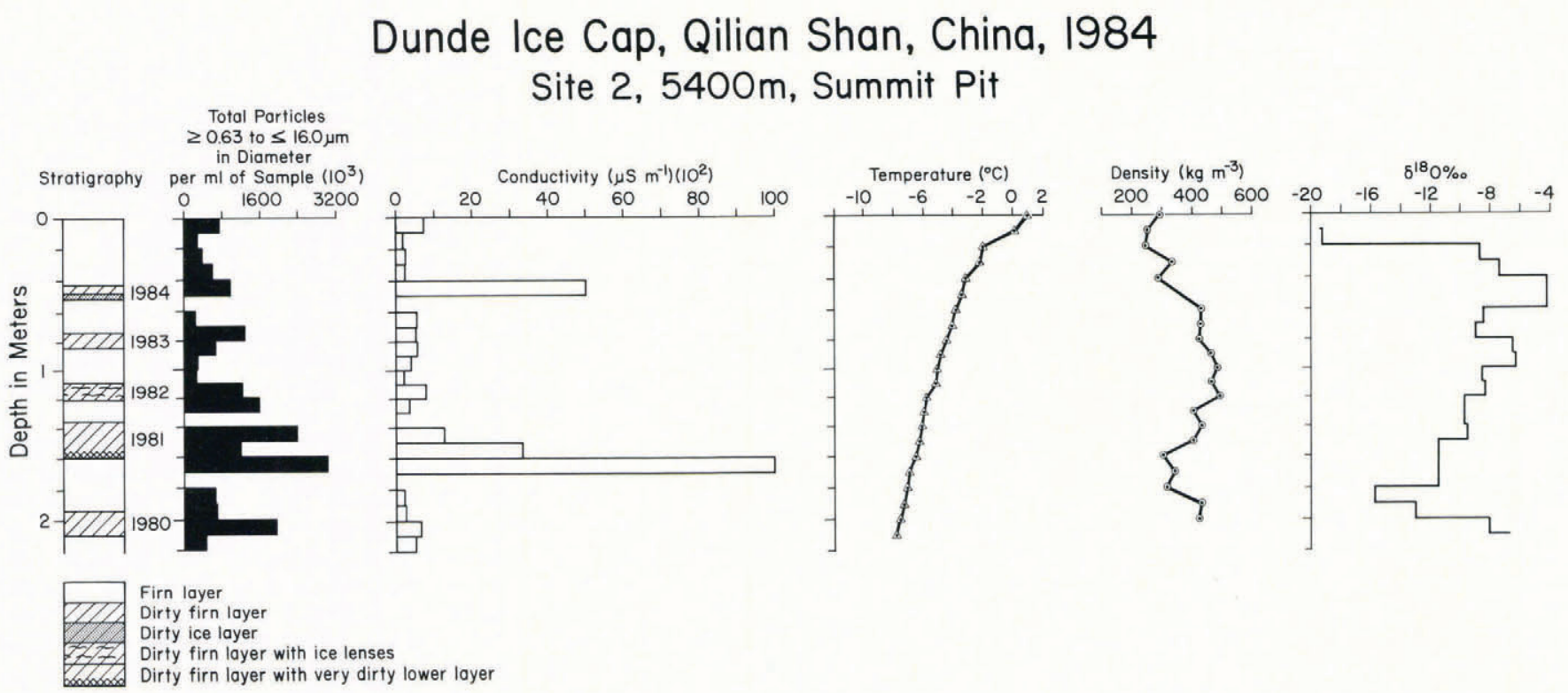

Fig.4. The stratigraphy, concentration of microparticles (diameters $\$ 0.63$ and $\leqslant 16.0 \mu \mathrm{m}$ per $\mathrm{ml}$ sample), liquid conductivity, temperature, density, and oxygen-isotope measurements from the pit at site 2 on the summit of the Dunde ice cap.

the stratigraphy, temperature, and density profiles. The separation between the visible dust layers, coupled with the densities, gives an annual accumulation average of $\simeq 170 \mathrm{~mm}$ of water from 1980 to 1984 . All three snow pits contained five distinct dust layers, but the ice layers were not as well developed in the summit pit, due to less extensive summer melting. All three pits contained a large conductivity peak in 1981. The oxygen-isotope records are similar in all three pits, with mean values of $-10.0 \%$ and a maximum seasonal range of $15 \%$.
Figure 5 illustrates the visible stratigraphy, microparticle concentrations, and liquid conductivities for the 1986 summit snow pit. The microparticle and conductivity profiles reveal that a distinct annual dust pattern exists in the Dunde ice cap stratigraphy, and a great deal of year-to-year variability in dust deposition. The 1986 data are consistent with and reinforce the interpretations based on the 1984 data; together they indicate an average annual accumulation of about $200 \mathrm{~mm}$ water equivalent.

\section{Dunde Ice Cap, Qilian Shan, China, 1986 Site 2, 5400m, Summit Pit}

Particles

22.00 to $\leq 50.8 \mu \mathrm{m}$

in Diameter

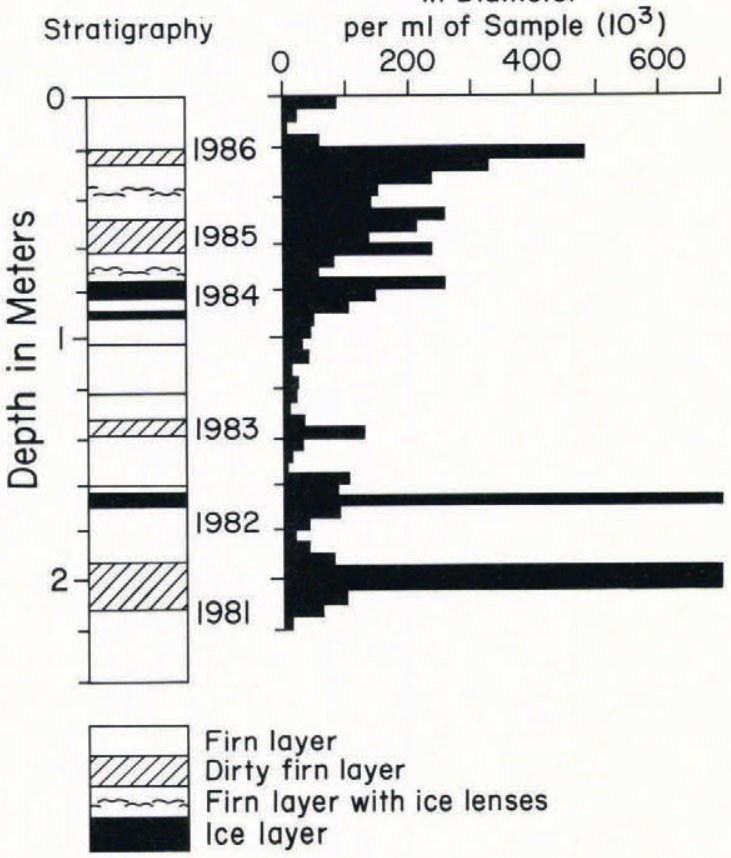

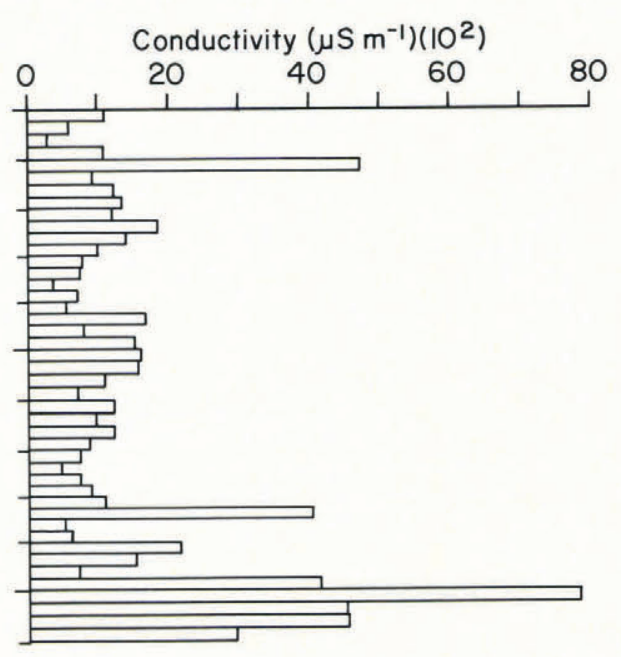

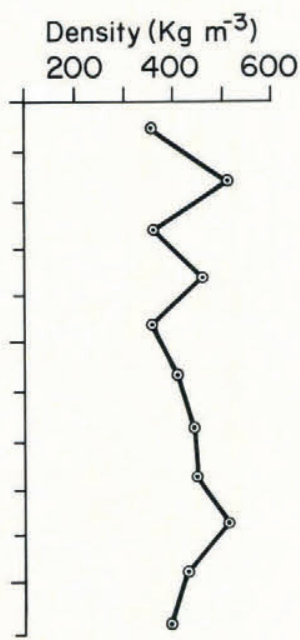

Fig.5. The stratigraphy, total concentration of microparticles (diameters $\geqslant 2.0$ and $\leqslant 50.8 \mu \mathrm{m}$ per $\mathrm{ml}$ sample), liquid-conductivity measurements, and density from a $2.2 \mathrm{~m}$ pit sampled in 1986 at the summit of the Dunde ice cap. 
The 1981 conductivity and microparticle peaks are dominant in both the 1986 and 1984 snow pits and provide a marker horizon across the ice cap. Field observations in 1986 indicate that the dust layers form during the ablation season in the fall, after the summer wet season (MaySeptember). The mean annual snow accumulation data for the summit, based upon 1984 and 1986 snow-pit microparticle and conductivity measurements, are presented in Table I. The net balance in water equivalent for the summit from 1980 to 1986 was calculated using the measured density profiles for each pit.

\section{TABLE I. NET BALANCE MEASUREMENTS FROM THE} SUMMIT OF THE DUNDE ICE CAP

\section{Water equivalent} (m)

$$
\begin{aligned}
& 1985-86 \\
& 1984-85 \\
& 1983-84 \\
& 1982-83 \\
& 1981-82 \\
& 1980-81
\end{aligned}
$$

$0.223^{*}$
$0.186^{*}$
$0.210^{*}$
$0.171^{*}$
$0.224^{*}$
$0.188^{* *}$

Average $\quad 0.200$

\section{*Based on six snow pits \\ **Based on one snow pit}

The Dunde ice cap is physically quite similar to the Quelccaya ice cap in southern Peru (Thompson and others $1979,1984[\mathrm{a}]$ and [b], 1986), from which a 1500 year ice-core record of tropical climate has been recovered (Thompson and others 1985). Much of this similarity between the Dunde and Quelccaya ice caps results from the very distinct annual precipitation cycle which dominates the climatic regime at both sites and which produces the annual dust layers visible in the stratigraphy of both ice caps. A 28 year precipitation record from the city of Golmud, located $235 \mathrm{~km}$ south-west of the Dunde ice cap, demonstrates that $85 \%$ or more of the precipitation falls in the summer months (May-September). The Dunde and Quelccaya ice caps are of similar size, $60 \mathrm{~km}^{2}$ and $55 \mathrm{~km}^{2}$ respectively, and are of similar thickness, $167 \mathrm{~m}$ and $175 \mathrm{~m}$ respectively.

On the other hand, in some respects these ice caps are quite different. The $30 \mathrm{~m}$ ice temperatures are much lower $\left(-5.4^{\circ} \mathrm{C}\right)$ in the Dunde ice cap than in the Quelccaya ice cap $\left(-0^{\circ} \mathrm{C}\right)$. The annual temperature pattern, as recorded at Golmud, shows a mean monthly temperature range of $30^{\circ} \mathrm{C}$, whereas that on the Quelccaya ice cap is $2^{\circ}-3^{\circ} \mathrm{C}$. Initially, it was anticipated that this temperature pattern, characteristic of the Tibetan highlands, would produce the most negative $\delta^{18} \mathrm{O}$ values within winter snowfall, as found in the polar regions. However, the surface samples (Figs.3a and b, Fig.4) show that the lowest (most negative) $\delta^{18} \mathrm{O}$ values occur in summer snowfall, which is identical with the relationship on the Quelccaya ice cap. One of the objectives of the continuing studies on the Dunde ice cap is to understand better the mechanisms controlling the annual oxygen-isotope signal.

The annual dust layers, visible both in the pit stratigraphy and on the exposed margin of the Dunde ice cap, in conjunction with the analyses of pit and core samples, suggest strongly that an ice core drilled to bedrock (as planned for 1987) should provide a climatic record covering at least 3000 years. However, because of the lower accumulation on the Dunde ice cap $(0.2 \mathrm{~m}$ of water equivalent versus $1.15 \mathrm{~m}$ on the Quelccaya ice cap) and the evidence of seasonal melting, the temporal resolution is not expected to be as high as on the Quelccaya ice cap. Nevertheless, the cores from the Dunde ice cap should provide an excellent opportunity to obtain a detailed history of the Little Ice Age as recorded in the Tibetan highlands. In addition, the long and well-documented historical records from central and eastern China will allow the upper 2000 years of the record to be calibrated and will provide independent dating checks on the ice-core chronology.

\section{ACKNOWLEDGEMENTS}

The 1984 research was conducted under a co-operative program sponsored by the National Academy of Science's National Program for Advanced Study and Research in China and the Academia Sinica of China. We thank Robert Geyer, former Director of the National Program for Advanced Study and Research in China, for his special efforts in helping make this program a success. The 1986 research was supported by NSF grant ATM-8519794, jointly funded by the Office of Climate Dynamics, and the Division of Polar Programs, the National Geographic Society grant no. 3323-86, and the Academia Sinica of China. We thank Mary Davis for assistance in the microparticle laboratory analysis, Pieter Grootes of the University of Washington for the oxygen-isotope analyses, Kathy Doddroe for typing and Robert Tope for illustrations. This paper is contribution 584 of the Byrd Polar Research Center, the Ohio State University.

Note: In 1987 three ice cores were recovered to bedrock. The depths were 136, 138 and $139 \mathrm{~m}$.

\section{REFERENCES}

Flohn H 1957 Large-scale aspects of the summer monsoon in south and east Asia. Journal of the Meteorological Society of Japan. 75th Anniversary Volume: 108-136

Flohn H 1965 Thermal effects of the Tibetan Plateau during the Asian monsoon season. Australian Meteorological Magazine 49: 55-58

Flohn H 1968 Contributions to a meteorology of the Tibetan highlands. Fort Collins, $\mathrm{CO}$, Colorado State University. Department of Atmospheric Science (Report 130)

Higuchi K (ed) 1976 Glaciers and climates of Nepal Himalayas. Report of the Glaciological Expedition of Nepal. Seppyo 38 Special Issue

Higuchi K (ed) 1977 Glaciers and climates of Nepal Himalayas. Report of the Glaciological Expedition of Nepal. Part II. Seppyo 39 Special Issue

Higuchi K (ed) 1978 Glaciers and climates of Nepal Himalayas. Report of the Glaciological Expedition of Nepal. Part III. Seppyo 40 Special Issue

Higuchi K (ed) 1980 Glaciers and climates of Nepal Himalayas. Report of the Glaciological Expedition of Nepal. Part IV. Seppyo 41 Special Issue

Higuchi K (ed) 1984 Glacier studies in Langtang Valley. Report of the Glacier Boring Project 1981-82 in the Nepal Himalaya. Tokyo, Japanese Society of Snow and Ice. Data Centre for Research

Koteswaram P 1958 The easterly jet stream in the tropics. Tellus 10(1): $43-87$

Lau K M, Li M T 1984 The monsoon of East Asia and its global associations - a survey. Bulletin of the American Meteorological Society 65(2): 114-125

Luo H, Yanai M 1983 The large scale circulation and heat sources over the Tibetan Plateau and the surrounding area during the early summer of 1979. Part I. Precipitation and kinematics. Monthly Weather Review 111: $922-944$

Mayewski P A, Lyons W B, Ahmad N, Smith G, Pourchet M 1984 Interpretation of the chemical and physical time-series retrieved from Sentik Glacier, Ladakh Himalaya, India. Journal of Glaciology 30(104): 66-76

Murakami T 1958 The sudden change of upper westerlies near the Tibetan Plateau at the beginning of the summer season. Journal of the Meteorological Society of Japan 36: 239-249 [in Japanese]

Murakami T 1981 Orographic influences of the Tibetan Plateau on the Asiatic winter monsoon circulation. Part I. Large-scale aspects. Journal of the Meteorological Society of Japan 59: 66-84

Niewodniczański J, Grabczak J, Barański L, Rzepka J 1981 The altitude effect on the isotopic composition of snow in high mountains. Journal of Glaciology 27(95): 99-111

Reiter E R 1983 Teleconnections with tropical precipitation surge. Journal of the Atmospheric Sciences 40(7): 1631-1647

Shi Y, Wang J 1981 The fluctuations of climate, glaciers and sea level since late Pleistocene in China. International Association of Hydrological Sciences Publication 131 (Symposium at Canberra 1979-Sea Level, Ice and 
Climatic Change): 281-293

Thompson L G, Hastenrath S, Morales Arnao B 1979 Climatic ice core records from the tropical Quelccaya Ice Cap. Science 203(4386): 1240-1243

Thompson L G, Mosley-Thompson E, Morales Arnao B 1984[a] El Niño-southern oscillation events recorded in the stratigraphy of the tropical Quelccaya Ice Cap, Peru. Science 226(4670): 50-53

Thompson L G, Mosley-Thompson E, Grootes P M, Pourchet M, Hastenrath S 1984[b] Tropical glaciers: potential for ice core paleoclimatic reconstructions. Journal of Geophysical Research 89(D3): 4638-4646

Thompson L G, Mosley-Thompson E, Bolzan J F, Koci B R 1985 A 1500-year record of tropical precipitation recorded in ice cores from the Quelccaya Ice Cap, Peru. Science 229(4717): 971-973

Thompson L G, Mosley-Thompson E, Dansgaard W, Grootes P M 1986 The Little Ice Age as recorded in the stratigraphy of the tropical Quelccaya Ice Cap. Science 234(4774): $361-364$

Virgi H Unpublished Summer circulation over South America from satellite data. (PhD thesis, University of Wisconsin, 1979)

Wang Z (ed) 1981 Glacier inventory of China. I. Qilian Mountains. Lanzhou, Academia Sinica. Lanzhou Institute of Glaciology and Cryopedology

Yeh T C 1981 Some characteristics of the summer circulation over the Qinghai-Xizang (Tibet) Plateau and its neighborhood. Bulletin of the American Meteorological Society 62: 14-19 